\title{
The Impact of the Flipped Classroom Model on Students' Academic Achievement
}

Emine Cabi, PhD.

Başkent University

\begin{abstract}
The aim of this study is twofold. First, it aims to investigate the impact of the Flipped Classroom (FC) Model on students' academic achievement. Second, it reveals the students' opinions about the model itself. For four weeks, the students in the experimental group were taught in a blended learning context where the FC Model was applied, while the lessons in the control group were carried out through traditional blended learning. Both groups were administered a test before and after the Flipped Classroom sessions. To analyze the data, a two-way ANOVA for Mixed Measures was conducted to compare the means of test scores of each group. The results showed that there were no statistically significant differences between the scores of the two groups. Coming to classes prepared and completing the assignments in class, so that students did not need to do assignments at home, were among the positive aspects of the FC Model. The problems encountered in this model, however, are categorized under three main titles: Motivation, Content, and Learning. At the end of the study, the advantages and disadvantages of the FC Model are identified in accordance with the participants' opinions, and necessary suggestions made.
\end{abstract}

Keyword: flipped classroom, students achievement, Khan Academy 


\section{Introduction}

The use of the flipped classroom as an alternative to the traditional learning environments has been increasingly attracting the attention of researchers and educators. The advancement in technological tools such as interactive videos, interactive in-class activities, and video conference systems paves the way for the widespread use of flipped classrooms (Johnston, 2017). It is even asserted that the flipped classroom, which is used to create effective teaching environments at schools, is the best model for using technology in education (Hamdan, McKnight, McKnight, \& Arfstrom, 2013). Studies about the flipped classroom appear in different disciplines including information systems (Davies, Dean, \& Ball, 2014), engineering, sociology, and humanities (Kim, Kim, Khera, \& Getman, 2014), mathematics education (Zengin, 2017), and English composition (Zhonggen, \& Wang, 2016).

\section{Who's Flipping?}

The FC Model is a new pedagogical model where the instructor shares predetermined digital resources with students through a platform outside the classroom, and related content is also taught through this outside platform asynchronously (Bergmann \& Sams, 2012). Inside the classroom, active, collaborative, and interactive problem-solving activities and consolidation practices are carried out (Toto \& Nguyen, 2009). Thus, learners are more active in the class, internalizing the contents through a wide range of classroom tasks (Crouch \& Mazur, 2001). Bishop and Verleger (2013) contended that a flipped classroom is an educational technique which consists of two significant components: (1) the use of computer technologies such as video lectures and (2) the involvement of interactive learning activities.

Moreover, lessons should include four major components in order to be entitled as the Flipped Classroom (Flipped Learning Network [FLN], 2014). First, educators should restructure the learning environment and time in a flexible way, considering the individual and group expectations and needs. Second, instructors need to teach the contents in detail, adopting a learner-centered approach and provide rich learning opportunities and activities reflecting a particular learning culture for the specific groups of students. Third, educators should regularly keep track of the difficulty level of the contents and the notes taken by the students as well as their progress, and they also apply active learning strategies that will maximize conceptual understanding of the students. Finally, the instructor should be a professional educator who continuously monitors students in their learning processes, immediately provides feedback, and assesses students' outputs.

Studies in related literature show that videos are often used as a means of teaching outside the classroom, while interactive tasks in which the students are actively participating are used as in-class activities (Basal, 2015; Graziano, 2017; Herreid \& Schiller, 2013; Hsu, 2017; Lage, Platt, \& Treglia, 2000; Roehling, Root Luna, Richie, \& Shaughnessy, 2017; Song \& Kapur, 2017; Zengin, 2017). Active participation and student-centered learning can be ensured through the use of videos that maintain students' attention and enable them to concentrate on the content (Herreid \& Schiller, 2013). Taking advantage of the technology, instructors both create video materials and make use of the open access videos available on the Internet (Sherer, \& Shea, 2011).

With the help of the instructor or their classmates, the students engage in the application-oriented learning activities to apply the theoretical knowledge (FLN, 2014). What is expected from the students 
in the classroom is to interact with the instructor and their peers, apply and practice the knowledge, and to use the opportunities provided to improve their learning performance and higher order thinking skills (Wiginton, 2013). In other words, it is fundamental that instructors apply active learning strategies to enable learners to manage their responsibilities, self-regulation, and learning process (Wiginton, 2013).

The essential principle of FC Model is to ensure better comprehension and consolidation of the content, which is learned by the students outside classroom, under the guidance of the instructors inside classroom (Herreid \& Schiller, 2013). After having concentrated on the topics while listening to the lectures or watching the videos outside the classroom, the students internalize them with the help of practical applications and interacting with the instructor in the classroom.

\section{Impacts of the FC on Student Learning}

In recent studies, the impacts of the FC Model on student performance, engagement, learning outcomes, and motivation have been investigated. Studies have shown that the FC approach enhances student's learning performance (Baepler, Walker, \& Driessen, 2014; Davies et al., 2013; Janotha, 2016; Sun \& Wu, 2016; Talley \& Scherer, 2013; Wiginton, 2013; Zengin, 2017; Zhonggen \& Wang, 2016), produces enhanced learning outcomes (Chen Hsieh, Wu, \& Marek, 2017; Gillispie, 2016; Kong, 2014; Smallhorn, 2017) and increases student motivation (Chyr, Shen, Chiang, Lin, \& Tsai, 2017; Graziano, 2017; Smallhorn, 2017; Wiginton, 2013; Yllmaz, 2017).

Although most of the research suggests that the FC Model positively impacts students' learning, there are also studies which have not revealed anticipated positive effects. For example, Smallhorn (2017) did not find an observable increase in students' academic achievement. In another study conducted by Kim et al. (2014), they stated that there was no evidence that the FC Model contributed to increased student grades. Similarly, in a study by Sun and Wu (2016), the use of the FC Model did not impact teacher-students interaction and learning satisfaction.

\section{Flipped Classroom and Students' Academic Achievement}

In recent years, several research studies have focused on the impacts of FC learning environments on students' academic achievements, one of which was conducted by Zengin (2017). In this study, the learning environment was designed using the FC Model alongside Khan Academy and free open source software (Zengin, 2017). The aim of this research was to investigate the impact of the FC Model on students' academic achievement and reveal their opinions about this model (Zengin, 2017). The participants of the study included 28 students in the Mathematics Teaching Program at a state university in Turkey, and the results of the study revealed that the FC learning environment, designed using both Khan Academy and mathematics software, doubled the students' academic success (Zengin, 2017). Moreover, it was found out that this learning approach facilitated student learning, enabled visualization in mathematics teaching, and contributed to permanent learning (Zengin, 2017).

In their mixed methods research, Zhonggen and Wang (2016) investigated the effectiveness of the FC Model on English writing courses. The data of the study were collected through a scale of satisfaction, a Business English writing test, and a structured interview (Zhonggen \& Wang 2016). As pre- and posttests, they administered the scale of satisfaction and a Business English writing test (Zhonggen \& Wang 2016). The findings showed that members of the experimental group, who were taught using the 
FC Model, scored higher on the aforementioned scales than the control group members, who were taught in a traditional learning environment (Zhonggen \& Wang 2016).

To illustrate the effectiveness of the FC Model, Janotha (2016) examined to what extent FC teaching affected the academic achievement of nursing students. The participants in the experimental taught trough FC Model and control groups taught through traditional pedagogy were administered a national standardized test and Council of Health Education System tests (Janotha, 2016). The test scores of the experimental group gained from the national standardized test were compared to those of the control group, and it was seen that the students in the experimental group achieved higher academic performance than the students in the control group (Janotha, 2016).

FC learning environments can also contribute to teachers' pre-service learning, skills, and affective development, specifically by creating a meaningful and authentic context for learning. Graziano (2017), for instance, conducted a study to uncover the benefits of the FC Model for pre-service teachers, its impacts on students' success, and the difficulties of the model. It was observed that learners were more productive and enthusiastic to participate in flipped lessons (Ray \& Powell, 2014). Firstly, this study is significant as relevant literature reveals that although there is an increase in studies related to the FC model throughout the world, there are a limited number of studies done in Turkey. Secondly, this study is significant because to the best of the researcher's knowledge, it is the first experimental study about the impact of FC Model on students' academic performance. Therefore, it is believed that it will contribute to a better understanding of the model and its effects on teaching and learning. Moreover, the findings of this particular study can contribute to develop FC Modeloriented courses in educational settings.

Although this model addresses to the needs and wants of students in the 21st century and offers contemporary solutions to current pedagogical problems, it is fundamental that more in-depth research be carried out to investigate the effectiveness of the FC Model. Despite the fact that many studies have been conducted on FC learning environments, there is not sufficient number of qualitative and quantitative studies regarding the impacts of this new field of study on the students' academic achievements, teaching processes, and learning process. Therefore, in order to identify the effects of the FC Model on students' academic achievement, this study aims to answer the following research questions:

1. To what extent does the Flipped Classroom Model affect students' academic performances?

2. What are the opinions of pre-service teachers about the Flipped Classroom Model?

\section{Method}

According to Johnson and Onwuegbuzie (2004), by not being limited to a single method of research, the researcher can answer their research questions comprehensively and thoroughly. Since quantitative data draw the overall picture of a problem, qualitative data is essential to reveal explanatory details (Johnson \& Onwuegbuzie, 2014). Therefore, this study was designed using a mixed-methods approach. The independent variables of the research are flipped classroom and traditional teaching approaches while the dependent variable is students' academic achievements. The study included two groups of participants (Table 1). First group was the experimental group who was 
taught using FC Model, and the second was the control group who was taught in a traditional learning environment. In both groups, courses were carried out in a blended learning environment, where each week, one hour of the course was conducted face-to-face and three hours were carried out online. The students' academic achievements were measured by administering a test before and after the treatment.

Table 1

Design of the Study

\begin{tabular}{|c|c|c|c|c|}
\hline & & Pretest & $\begin{array}{l}\text { Treatment } \\
\text { (4 week) }\end{array}$ & Posttest \\
\hline Experimental & $\mathrm{R}$ & Achievement Test & $\mathrm{X}_{\mathrm{FC}}$ & $\begin{array}{l}\text { Achievement Test- } \\
\text { Focus-group interview }\end{array}$ \\
\hline Control & $\mathrm{R}$ & Achievement Test & $\mathrm{X}_{\mathrm{TL}}$ & Achievement Test \\
\hline
\end{tabular}

Note. $\mathrm{R}=$ Unbiased Assignment $\mathrm{X}_{\mathrm{FC}}=$ Flipped Classroom; $\mathrm{X}_{\mathrm{TL}}=$ Traditional Learning.

\section{Participants of the Study}

The participants of the study consisted of 59 pre-service teachers studying in English Language Teaching and Turkish Language Teaching Programs, who were taking a "Computer I" course in the 2015-2016 Academic year. Before the treatment, all the participants received training for basic computer skills to avoid possible problems in effective use of computers throughout the experimental process.

The students were randomly assigned to the groups making sure that each group included students from both programs. At the beginning of the research, there were 67 students; however, eight participants were excluded from the study group at the end of the research because they either did not carry out the out-of-class activities, they did not participate in the classroom practices for one or two weeks, or they missed the posttest.

In the end, there were 28 students in the experimental group (22 female, 6 male students; 18 ELT students, 10 TLT students) and 31 students in the control group (27 female, 4 male students; 14 ELT students, 17 TLT students). Table 2 summarizes the information about the participants of the study.

Table 2

The Information About the Participants of the Study

\begin{tabular}{lllllll}
\hline & \multicolumn{2}{l}{$\begin{array}{l}\text { English language } \\
\text { teaching(ELT) }\end{array}$} & \multicolumn{2}{l}{$\begin{array}{l}\text { Turkish language } \\
\text { teaching(TLT) }\end{array}$} & Total & \\
\hline & $\mathrm{f}$ & $\%$ & $\mathrm{f}$ & $\%$ & $\mathrm{f}$ & $\%$ \\
Flipped learning & 18 & 64 & 10 & 36 & 28 & 47 \\
Traditional Learning & 14 & 45 & 17 & 55 & 31 & 53 \\
Total & 32 & 54 & 27 & 46 & 59 & 100 \\
\hline
\end{tabular}

Note. $\mathrm{f}=$ Number of participants.

\section{Content and the Procedure}


The necessary learning environments were designed for both groups to carry out the treatment. The general features of these learning environments are shown in Figure 1.

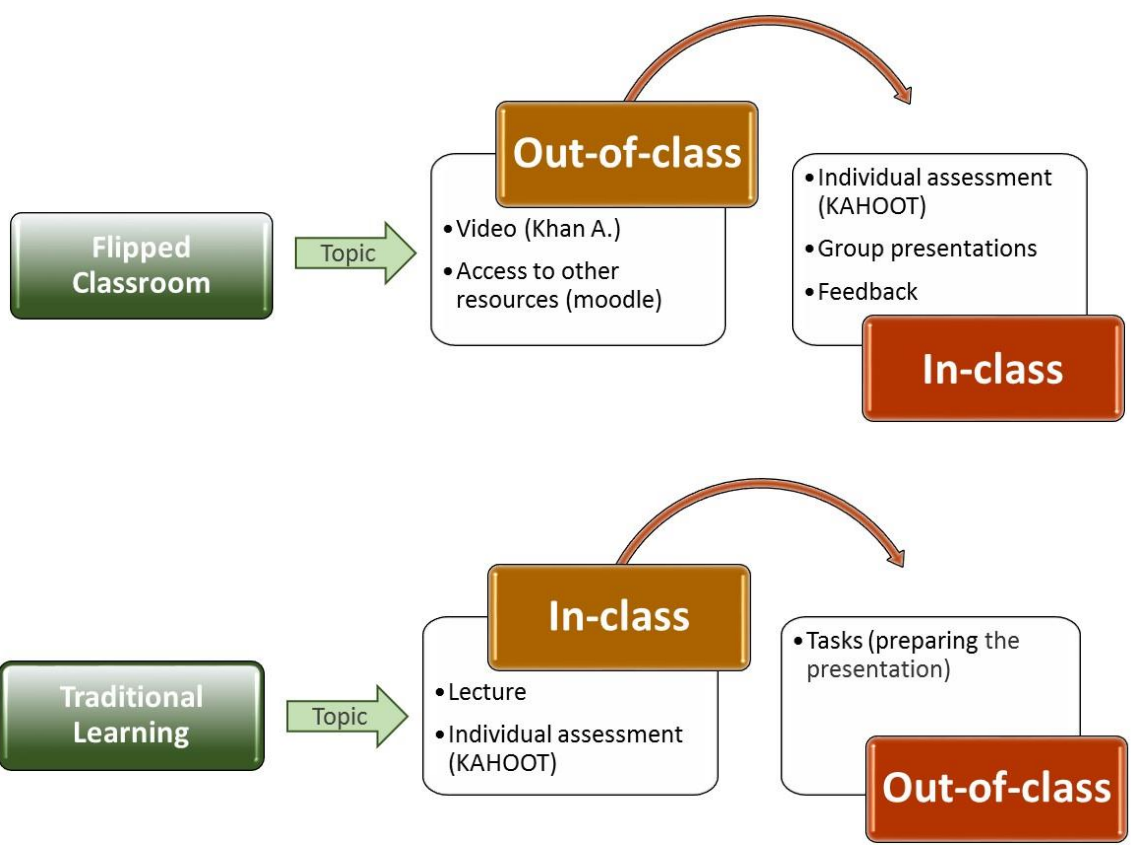

Figure 1. Features of learning environments for experimental group (flipped classroom) and control group (traditional learning).

\section{Experimental Group (Flipped Classroom)}

Studies conducted on the FC Model (Chen Hsieh et al., 2017; Herreid \&Schiller, 2013; Lage et al., 2000; Song \& Kapur, 2017) have led to the development of an Appropriacy Form for the flipped learning environment. This form includes in-class activities which focus on not only sub-skills such as remembering, understanding and applying, but also higher order thinking skills such as analyzing, evaluating, and creating as defined by Anderson (2005). To increase the validity of the form, five field experts were consulted for their opinions and suggestions about the form content, appropriacy, and comprehensibility. Based on their suggestions, necessary corrections and alternations were done. Accordingly, in-class and out-of-class activities were designed as shown in Table 3 and Figure 1.

Table 3

Appropriacy Form for Flipped Learning Environment

\begin{tabular}{lll}
\hline & $\begin{array}{l}\text { Out-of-class activity (Video, Khan } \\
\text { Academy) }\end{array}$ & In-class activity \\
\hline Week 1 & $\begin{array}{l}\text { What is information theory? }(3.16 \mathrm{~min} .) \\
\text { History of the alphabet }(9.55 \mathrm{~min} .) \\
\text { The Rosetta Stone }(4.43 \mathrm{~min} .)\end{array}$ & $\begin{array}{l}\text { Individual assessment: KAHOOT } \\
\text { Group presentations, Topic: The } \\
\text { Development of alphabet }\end{array}$ \\
\hline Week 2 & $\begin{array}{l}\text { Source encoding }(4.53 \mathrm{~min} .) \\
\begin{array}{l}\text { Visual telegraphs }(9.19 \mathrm{~min} .) \\
\text { Morse code and information age (10.5 } \\
\text { min.) }\end{array}\end{array}$ & $\begin{array}{l}\text { Individual assessment: KAHOOT } \\
\text { Group presentations, Topic: Tools } \\
\text { used to transfer knowledge }\end{array}$ \\
\hline
\end{tabular}




\begin{tabular}{lll}
\hline Week 3 & $\begin{array}{l}\text { Symbol rate (5.02 min.) } \\
\text { Introduction to channel capacity (6.09 } \\
\text { min.) }\end{array}$ & $\begin{array}{l}\text { Individual assessment: KAHOOT } \\
\text { Group presentations, Topic: The } \\
\text { Capacity of knowledge in digital } \\
\text { Assessing knowledge (11.16 min.) }\end{array}$ \\
\hline Week 4 & $\begin{array}{l}\text { A mathematical theory of communication } \\
\text { (4.29 min.) }\end{array}$ & $\begin{array}{l}\text { Individual assessment: KAHOOT } \\
\text { Group presentations, Topic: The }\end{array}$ \\
& $\begin{array}{l}\text { Information entropy } \\
\text { Compression codes (4.14 min.) } \\
\text { Error codes (5.19 min.) }\end{array}$ & $\begin{array}{l}\text { Factors facilitating knowledge } \\
\text { transfer in today's world }\end{array}$ \\
& \\
\hline
\end{tabular}

Throughout the procedure, course materials were provided through an online learning platform provided by Khan Academy. Khan Academy presents itself as a resource for individual learning where anybody can improve themselves via personalized education (Khan Academy, 2016). Videos presented to the students within our study were titled "Computer Science" and were retrieved from the "Computer World" category of the Khan Academy webpage (Khan Academy, 2016). As it is difficult to find high-quality, elaborate videos on the Internet, instructors prefer videos produced by resources such as Khan Academy (Herreid \& Schiller, 2013).

\section{Out-of-Class Activities}

In accordance with the weekly topics, URL addresses of the videos with the learning contents were sent to the students. The students were expected to come to the classroom prepared and having watched the assigned videos. Figure 2 illustrates one of the videos entitled "What is Information Theory?" under the category of "Learn/Computer World/Computer Science/Journey into Information Theory" (Khan Academy, 2016).

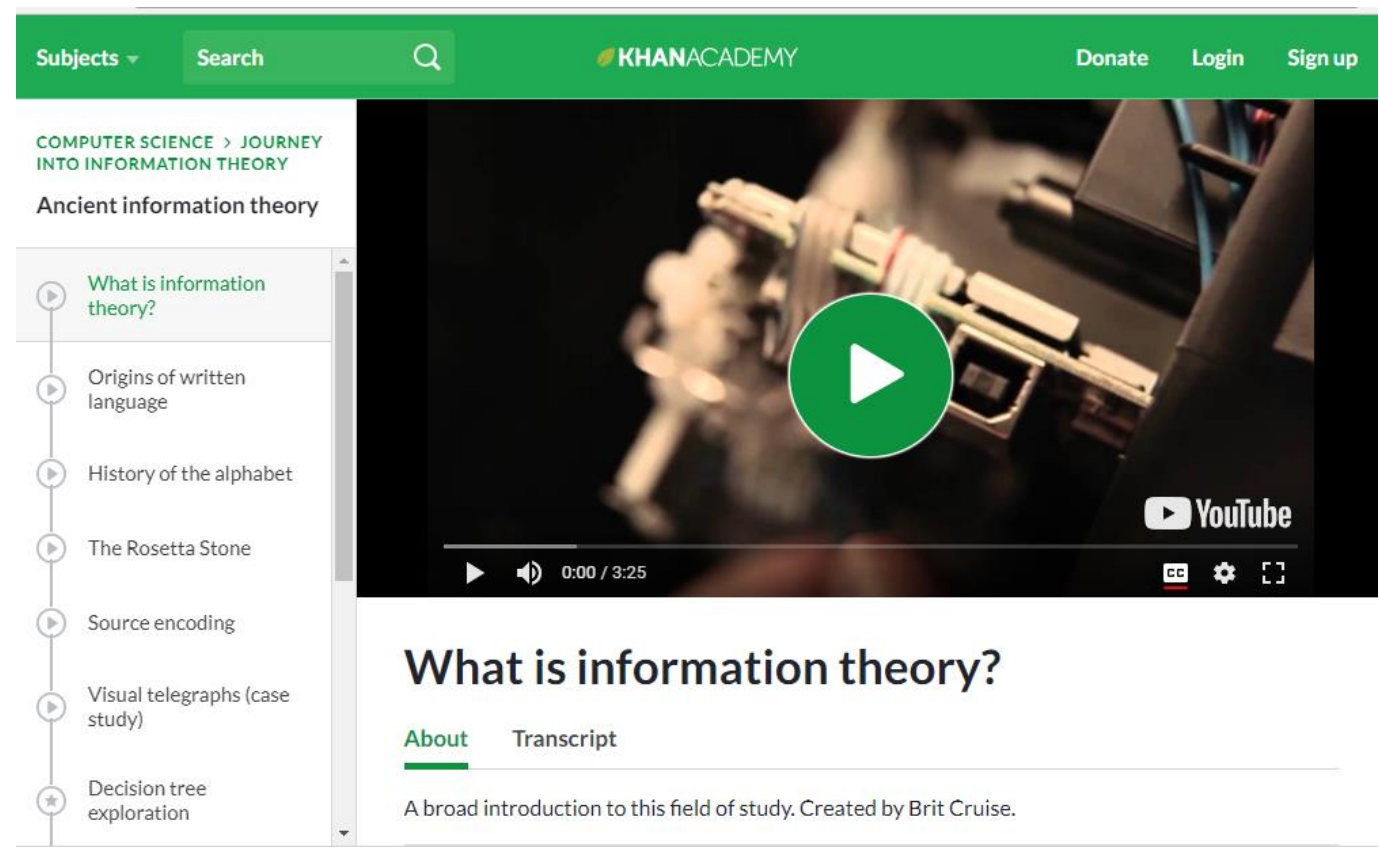

Figure 2. Screenshot of a video view. From "What is Information Theory?" by Khan Academy, 2016 (https://www.khanacademy.org/computing/computer-science/informationtheory/infotheory/v/intro-information-theory). 


\begin{tabular}{|c|}
\hline 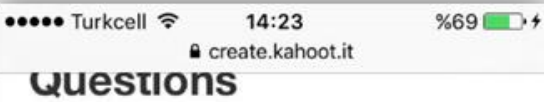 \\
\hline 1. İlk bilgisayarın adı nedir? \\
\hline $\begin{array}{l}\text { 2. Bilgisayarın beyni niteliğindeki } \\
\text { en önemli bileşendir.Tüm } \\
\text { işlemler,kontroller buradan yönetilir }\end{array}$ \\
\hline $\begin{array}{l}\text { 3. Steve Jobs ve Steve Wozniak'ın } \\
\text { evlerinin garajında tasarladıkları ilk } \\
\text { kişisel bilgisayarın ismi }\end{array}$ \\
\hline $\begin{array}{l}\text { 4. Resimdeki soruyu } \\
\text { cevaplandırını. }\end{array}$ \\
\hline $\begin{array}{l}\text { 5. Resimdeki soruyu } \\
\text { cevaplandırını. }\end{array}$ \\
\hline 6. Hangisi giriş birimi değildir? \\
\hline $\begin{array}{l}\text { 7. Illk bilgisayar ENIAC saniyede } \\
5000 \text { temel işlem,şimdiki } \\
\text { bilgisayarlar } 1 \text { milyar işlem yapar. }\end{array}$ \\
\hline $\begin{array}{l}\text { 8. Resimdeki soruyu } \\
\text { cevaplandırınız. }\end{array}$ \\
\hline
\end{tabular}

\begin{tabular}{|c|c|c|}
\hline \multicolumn{3}{|l|}{ Hafta 1} \\
\hline Played on & \multicolumn{2}{|l|}{27 Oct 2015} \\
\hline Hosted by & \multicolumn{2}{|c|}{ hhakancetinkaya } \\
\hline Played with & \multicolumn{2}{|l|}{15 players } \\
\hline Played & \multicolumn{2}{|c|}{6 of 6 ques tions } \\
\hline \multicolumn{3}{|l|}{ Overall Performance } \\
\hline Total correct answers (\%) & \multicolumn{2}{|c|}{$66,67 \%$} \\
\hline Total incorrect answers (\%) & \multicolumn{2}{|c|}{$33,33 \%$} \\
\hline Average score (points) & \multicolumn{2}{|c|}{3584,07 points } \\
\hline \multicolumn{3}{|l|}{ Feedback } \\
\hline How fun was it? (out of 5) & \multicolumn{2}{|c|}{5,00 out of 5} \\
\hline Did you learn something? & \multicolumn{2}{|c|}{$100,00 \%$ Yes } \\
\hline Do you recommend it? & \multicolumn{2}{|c|}{$100,00 \%$ Yes } \\
\hline How do you feel? & & 100,00\% Positive \\
\hline
\end{tabular}

Figure 3. A screen-shot sample of questions and results view. From "Kahoot Mobile App" by Kahoot Application, 2016 (https://kahoot.com/mobile-app/).

\section{In-Class Activities}

In-class activities included individual assessments and group presentations. Classes began with multiple-choice tests, comprised of five or ten questions about the contents learned outside of the classroom. The students logged in to the Kahoot application with their student numbers, using their smart phones to reach the interface and see the test uploaded into the system by the instructor. The students were expected to answer the questions within an allocated amount of time and send their responses through the same system. When the response time for each question ended, the correct answer and the students' own responses were projected. After all of the questions were responded to, the instructor shared the correct answers with the students using projection.

For the group presentations, at the beginning of the term, students were divided into groups of four. Within groups, each student was assigned one of the following roles: group leader, group presenter, writer, or reporter. Group members exchanged their roles weekly so that every student could perform each role at some point throughout the procedure. The groups were assigned a different topic each week and required to make a presentation within a given time period in the classroom (Table 3). Therefore, every student actively participated in the learning process inside the classroom.

\section{Control Group (Traditional Learning)}

The learning environment for the control group was organized in such a way that they were taught differently from the experimental group. Namely, out-of-class activities shown in Table 3 were applied in the classroom, and the in-class activities were done outside the classroom. The contents of the videos presented to the experimental group were lectured to the control group students by the instructor in the class. At the end of the lesson, the control group students were administered the multiple-choice test via the Kahoot application and evaluated on the system. The activities that the 
experimental group did in class, were given as outside-of-class assignments to the control group, and students were expected to prepare a presentation related to the research question. Unlike the experimental group, in which presentations were done in groups, the control group was required to prepare assignments individually. The students were assigned to make presentations individually about the topic of the week.

\section{Data Collection Tools}

In this study, multiple data collection tools were used. An achievement test was used to answer the first research question. Focus group interviews, on the other hand, were used to respond the second research question.

\section{Achievement Test}

In line with the time allocated to each topic, the appropriate number of questions was determined, and 25 multiple-choice items were written. These questions were compiled in a question pool and were evaluated by three field experts and an expert in the field of measurement and evaluation. Certain changes and revisions were done to some of the items based on the expert opinions. One item was excluded from the interview questions. Moreover, in accordance with the suggestions of the expert in measurement and evaluation, the items which tested the same topic were categorized together and sequenced in a linear way. Negative statements were avoided as much as possible, and if there were any, they were highlighted in the questions. In addition, the distracters were prepared appropriately. The experts also evaluated the questions to ensure whether they were compatible with the learning outcomes and taxonomy.

The achievement test which ultimately included 22 multiple-choice questions was administered to 58 students, item analysis was run, and a simple item analysis table was formed. The test items were prepared in such a way that they distinguished between students who are knowledgeable, and those who are not, or between masters and non-masters students. The analysis revealed no items with negative item discrimination. Among all the items, only two had a lower item discrimination index (i.e., 0.3 and 0.29). The item difficulty index, however, was 0.42 and 0.41 . After consulting our experts' opinions and doing the necessary revisions, the items were kept in the test. For the internal reliability of the test, the Kuder-Richardson Formula 20 (KR-20) was run, and reliability coefficient was found 0.74, which indicates internal reliability.

\section{Focus-Group Interview}

All of the interview questions were developed after a detailed literature review in the relevant field, and piloting. In qualitative studies, to increase the validity of the results, it is crucial that the researcher directly quote the opinions of the participants and use these quotes to discuss the findings (Ylldirım \& Şimşek, 2008). The findings should include the participants' words rather than subjective statements of the researcher (Lincoln and Guba, 1985). In our study, dense description was used in order to ensure transferability, which shows the validity of the focus group interview questions. The coded data was examined for their conformability. In the analysis procedure, a coding list was formed, and these codings were peer reviewed. After the analyses, another expert coded and interpreted some parts of the interview data by means the same coding list. The results of the two analyses were compared, and the differences were discussed and negotiated. 
After the treatment was completed, the researcher formed groups of four or five and asked open-ended questions to the students. To ensure reliability and validity of the focus group interview questions, expert opinions were also consulted. A total of 18 students participated in the focus group interviews including 4 male and 14 female students. The interviews were audio recorded, and the duration of these interviews ranged from 7 to 13 minutes. To reveal the opinions of the participants about the FC Model, the following questions were asked during the focus-group interview.

- How much study time (how many hours) per week did you allocate for your out-of-class lessons?

- What did you specifically do in order to learn the topics outside the classroom?

- What are the positive aspects of the Flipped Classroom for you?

- What is the application that you like the most in this model?

- What are the problems you have encountered in FC Model?

- What solutions do you suggest to solve the problems experienced?

\section{Data Analysis}

A 2x2 split-plot design was used to analyze the quantitative data. Two-way ANOVA for Mixed Measures was used to designate the main effects for column and row factors and their interaction effect related to the effectiveness of the experimental study (Büyüköztürk, 2016). The qualitative data gathered through the focus-group interviews, however, were analyzed though descriptive analysis. In line with descriptive analysis techniques, the data were organized according to the themes (general themes and sub-themes) that emerged from the interview questions and research questions. Moreover, while listing the results of the study, direct quotations were also provided from the participants' responses to the interview questions because in descriptive analysis it is important to make use of direct quotations from the participants' and discuss the findings based on these quotations to ensure validity (Yıldırım \& Şimşek, 2008).

\section{Results}

\section{The Impacts of the Flipped Classroom on Students' Academic Achievement}

An unrelated t-test was performed to identify whether there were any statistically significant differences between the pre-test scores of the two groups. Table 4 displays the results of the unrelated t-test.

Table 4

The Results of the Unrelated T-test According to the Pre-test Scores of the Groups

\begin{tabular}{lcccccc}
\hline $\begin{array}{l}\text { Measurement } \\
\text { (Group) }\end{array}$ & $n$ & $M$ & $S D$ & $S E$ & t-test & $p$ \\
\hline Experimental & 28 & 3,5000 & 1,13855 & 57 & 0.71 & 0.478 \\
Control & 31 & 3,2903 & 1,11396 & & & \\
\hline
\end{tabular}


Note. $\mathrm{P}<.05 ; \mathrm{n}$, the number of students; $\mathrm{M}$, arithmetic average; SD, standard deviations; SE, standard error.

Table 4 displays that there were no statistically significant differences between the mean scores of the students $(\mathrm{t}(57)=0.71, \mathrm{p}>0.05)$. Based on this finding, it can be stated that both groups can participate in the experimental process. Table 5 shows the standard deviation values and the means of the preand post-test scores of the students in the experimental and control groups.

Table 5

Achievement Test Scores of the Experimental and Control Groups

\begin{tabular}{lrrrrr}
\hline \multirow{2}{*}{ Groups } & \multicolumn{2}{c}{ Pre-test } & & \multicolumn{2}{c}{ Post-test } \\
\cline { 2 - 4 } \cline { 5 - 5 } & $M$ & $S D$ & & & \\
\hline Experimental & 58.33 & 18.976 & 55.29 & 16.11 \\
Control & 54.84 & 18.56 & 56.64 & 14.79 \\
\hline
\end{tabular}

Note. SD, standard deviations; $\mathrm{M}$, arithmetic average.

As observed in Table 5, while the pre- and post-test mean scores of the experimental group decreased (from 58.33 to 55.29), the mean scores of the control group increased (from 54.84 to 56.64 ).

The findings related to whether the changes in the students' scores show statistically significant differences depending on the FC Model and traditional blended-learning are shown in Table 6 . Accordingly, no significant differences were found in the means of the pre- and post-test scores of the two groups $\left(\mathrm{F}_{(1,57)}=0.926, \mathrm{p}<0.05, \eta 2=0.016\right)$. To identify the effect size and the significance of the differences between each of the groups, eta square ( 12 ) was examined. According to Cohen (1988), if $\eta 2<.02$, it is grouped as small. Since the effect size was found to be small ( $\eta 2=0.016)$, it can be said that different learning environments explain a very small part of the total variance of the academic performance.

Table 6

The Results of ANOVA on the Students' Pre- and Post-test Scores in Accordance With the FC Model and Traditional Learning

\begin{tabular}{|c|c|c|c|c|c|c|}
\hline Variance Source & SS & df & MS & F-value & $\mathbf{P}$ & $\eta 2$ \\
\hline Between-Groups & 23001.37 & 58 & & \multirow{3}{*}{.083} & \multirow{3}{*}{.774} & \multirow{3}{*}{0.001} \\
\hline Group(Experimental/Control) & 33.54 & 1 & 33.54 & & & \\
\hline Error & 22967.84 & 57 & 402.94 & & & \\
\hline
\end{tabular}




\begin{tabular}{|c|c|c|c|c|c|}
\hline Within-Groups & 10852.71 & 59 & & & \\
\hline Measurement /Pre-test/Post-test) & 11.33 & 1 & 11.33 & .061 & 0.001 \\
\hline Group ${ }^{*}$ Measurement & $173 \cdot 32$ & 1 & $173 \cdot 32$ & .926 & 0.016 \\
\hline Error & 10668.05 & 57 & 187.156 & & \\
\hline Total & 21694.08 & 117 & & & \\
\hline
\end{tabular}

Note. $\mathrm{P}<.05$; ANOVA, analysis of variance; SS, sum of squares; df, degrees of freedom; MS, mean square ; $\eta 2$, measure of strength of relationship (eta squared) ; $n$, the number of students.

In other words, the difference between the mean scores of the students learning through the FC Model and traditional blended learning was not statistically significant. There was even a small decrease observed in the mean scores of the students taught through FC as seen in Table 5 .

\section{What are the opinions of the pre-service teachers regarding the FC Model?}

How much study time (how many hours) per week did you allocate for your outof-class lessons? The students were asked how much time they studied outside the classroom. Out of 18 students, 16 stated that they spent one-two hours studying outside the classroom, 1 student reported spending three-four hours, the other student four-five hours.

What did you specifically do in order to learn the topics outside the classroom? When the students were asked what they specifically did in order to learn the topics outside the classroom, 14 of them expressed that they watched videos, and 10 students stated they revised and summarized the topics (See Table 7). Revision and summarization are specifically used learning strategies.

Table 7

Pre-Service Teachers' Opinions

\begin{tabular}{lll}
\hline Question & Answer & F \\
What did you specifically do in order to learn & I watched the suggested videos. & 14 \\
the topics outside the classroom? & I revised and summarized the topics. & 10 \\
& I did not do anything extra. & 1 \\
\hline What are the positive aspects of Flipped & We come to the class prepared. & 4 \\
Classroom for you? & $\begin{array}{l}\text { I do not need to do assignments outside } \\
\text { the class. }\end{array}$ & 4 \\
& We learn the topic outside the class and & 2 \\
& consolidate them in the class. & \\
& It is fun to do the assignments as a & 2 \\
& group in the classroom. & \\
& I do not think it has a positive aspect. & 1 \\
\hline What is the application that you like the most & Kahoot & 12 \\
& Khan academy videos & 2 \\
in this model? & Moodle & 1 \\
& Group work & 1 \\
\hline
\end{tabular}

Note. F, number of students.

What are the positive aspects of the flipped classroom for you? When the students were asked about the positive aspects of the FC Model, four students stated they could come to the 
class prepared. Following this answer, they expressed that other positive aspects included that they did not have to do assignments outside the classroom, and that they learned the topic outside the class and consolidated this learning in the class. One student emphasized the fact that doing assignments as a group in the class was more enjoyable than doing assignments individually outside the classroom. Furthermore, another student indicated that self-learning enabled her to increase her self-confidence by saying, "I gained the courage and pleasure that I myself can understand a topic which is totally new to me, and if I want to, I can comprehend and learn it better."

What is the application that you like the most in this model? As can be seen in Table 7, the application that students (12 students) liked the most in FC Model was Kahoot. The students found it enjoyable to log in this application through their smart phones or Internet-enabled computers at the end of each topic in the classroom to evaluate their own performances. Additionally, two students stated that they enjoyed Khan Academy videos, one student expressed positive feelings towards Moodle, and one from the group works.

What are the problems you have encountered in FC Model? The students were also asked what problems they encountered while learning through the FC Model. The rest of the answers were categorized under three major themes (See Table 8). Accordingly, eight students stated they experienced motivation problems; nine students encountered problems related to the lesson content, and four students encountered problems related to learning. Six students said they did not experience any problems.

Table 8

Problems Encountered in the FC Model

\begin{tabular}{lll}
\hline Category & Problem & F \\
\hline Motivation & I did not want to put an effort on it. & 3 \\
& I felt burn out. & 3 \\
& The topics were boring and unnecessary. & 2 \\
\hline Content & The topics were difficult, so I could not understand. & 3 \\
& The resources were not sufficient. & 5 \\
& There were many terms. & 1 \\
\hline Learning & I had time constraints, so I could not study. & 3 \\
& I had difficulty relating the topic of the lesson to my & 1 \\
\hline Other & field of study. & 6 \\
\hline
\end{tabular}

Note. F, number of students. Problems listed are direct quotes from participants.

What solutions do you suggest to solve the problems experienced? As for the possible solutions to the problems they experienced, four students responded, "Instead of studying the topics outside the classroom, I would like to learn them from the instructor." The other answers from three students are as in the following: 
- $\quad$ Actually, I do not want to do the assignments outside the classroom. Since I do not have a serious environment, I constantly procrastinate and cannot concentrate. I am in favor of learning the lesson and doing the activities in the class."

- "Instead of video lecturing, the instructors can teach us in the classroom, then we can watch the videos later at home."

- To teach the lesson and carry out the activities in the class since students never do the assignments."

Lastly, the students were also asked what their opinions were to further improve this model. Five students reported that the instructor should explain the topics to study at home, and three students stated that they should be provided with more resources for out-of-class study.

\section{Conclusion}

The main purpose of this study is to investigate the impacts of the FC Model on students' academic achievements. To this end, two study groups were formed: an experimental group including students learning through the FC Model, and a control group including participants taught through traditional blended learning. Before the four-week treatment procedure, a relational t-test was run, and it was found out that there were no statistically significant differences between the groups. To reveal the impacts of the FC model on the students' academic achievement, a two-way ANOVA for Mixed Measures was used to see whether there were significant differences between the pre- and post-test scores of the experimental group and control group. The results indicated that there were no statistically significant differences between the scores of each group. Namely, the findings showed that the use of the FC Model does not yield significant impacts on increasing the students' academic achievement. Only a few other studies supporting this finding (Kim et al., 2014; Smallhorn, 2017). Conversely though, the results of related studies in the relevant literature reflect that the FC Model increases students' academic success (Janotha, 2016; Pierce \& Fox, 2012; Talley \& Scherer, 2013; Zengin, 2017).

Alongside the positive and negative impacts of the FC Model, the reasons why the results of this study were not compatible with those of the previous research in the field were also identified by reviewing the focus-group interviews. These interviews revealed that the total study time of the students outside the classroom was only 1-2 hours. According to this finding, it is seen that the working time of the students outside the class is 1-2 hours. Besides, it was stated that they watched the videos assigned and suggested in order to learn the topics outside the classroom. While studying, they used learning strategies such as revising and summarizing the contents. Learning strategies are the strategies which promote individuals' self-learning process. They consist of behaviors and thoughts that are expected to affect the way learners choose, organize, and integrate the new information to learn (Weinstein \& Mayer, 1986). As cognitive learning strategies, the rehearsal strategy involves repetition, and elaboration includes summarization (Pintrich, 2000). The findings of this particular study show that while learning within the FC Model, the pre-service teachers are successful at using rehearsal and elaboration learning strategies. In line with this finding, Wiginton (2013) asserts that using learning strategies to ensure student responsibility, self-regulation, and autonomous learning are among the FC Model's advantages. 
According to the students, coming to classroom prepared and completing the assignments in the class so that they do not have to do them at home are among the positive aspects of this model. Moreover, doing the assignments as a group under the guidance of the instructor motivates the students. Sun \& $\mathrm{Wu}$ (2016) emphasized positive impacts of group work done in the class on the students' performances. In fact, they revealed that classroom interaction (within the context of group work) positively impacts students' academic achievements (Sun \& Wu, 2016). Studying autonomously and reaching their goals on their own help students gain the feeling of self-confidence. According to Chyr et al. (2017), for example, flipped learning practices could be helpful for students' participation, selfefficacy, and self-directed learning. Moreover, relating the contents to real life is likely to attract the students' attention (Kong, 2014). With this information in mind, we suggest that images in the videos used within a FC reflect the classroom environment, and that activities should be organized on the basis of the learners' needs and interests.

Our findings also reveal that in general, students resist learning the topics on their own outside the classroom in the FC Model. Instead they prefer learning the topics from the instructor inside the class. The problems encountered in this model can be categorized under three main titles: Motivation, Content, and Learning. As reported by our participants, in a new learning environment, students who are typically willing to put effort into learning tend to have difficulty getting motivated. The students studying outside the classroom stated they experienced problems regarding the difficulty of the contents and insufficiency of the resources. Among the other problems were lack of time to study outside the class, difficulty in understanding the topics, and learning difficulty. In their research, Chen Hsieh et al. (2017) pointed out that many students had difficulties adapting to the FC Model since it is a new approach. Most of the students stated that the course included heavily-loaded requirements, and they did not have time to watch the videos outside the class (Chen Hsieh et al., 2017).

Siegle (2014) also puts forward a similar idea in his study. Siegle asserts that students may not be successful at completing the learning contents while watching the videos outside the classroom. Moreover, students' motivation problems may result from the low readiness level for e-learning. In a study conducted by Yllmaz (2017), the relation between motivation and readiness level was examined. It was found out that students' e-learning readiness level was a significant predictor of their satisfaction and motivation (Yllmaz, 2017). Apart from the effectiveness of the FC Model, Yilmaz asserts that there is a need to identify students' readiness level for e-learning in order to increase their satisfaction and motivation.

Even if the instructors have problems in producing videos appropriate to the student's level (Siegle, 2014), they can both create video materials benefitting from the advantages of technology and make use of open-access video materials available on the Internet. Moreover, it is suggested that instructors use Khan Academy videos. The students' opinions show that it can be beneficial to use Kahoot as an assessment tool, and Khan Academy videos as video materials. Another suggestion is that instructors should provide a brief explanation in the class about the assignments that the students are supposed to complete outside the classroom.

This study is limited in the sense that it was carried out with a small number of students taking the "Computer I" course. Similar research should be conducted with a larger sample, in different courses, and at different levels of education, so that it will be possible to generalize the findings. Moreover, 
using different data collection tools in addition to the pretest, posttest, and focus group interview may yield a more in-depth and multi-faceted analysis of the students' opinions and academic achievements. Furthermore, it is recommended that students' motivation and readiness level to learn outside the classroom be identified and necessary arrangements be done before applying the FC Model. Lastly, rich content videos should be chosen and produced specifically for students to consult for out-of-class studies. 


\section{References}

Anderson, L. W. (2005). Objectives, evaluation, and the improvement of education. Studies in Educational Evaluation, 31(2), 102-113. doi : 10.1016/j.stueduc.2005.05.004

Baepler, P., Walker, J., \& Driessen, M. (2014). It's not about seat time: Blending, flipping, and efficiency in active learning classrooms. Computers \& Education, 78, 227-236. doi: 10.1016/j.compedu.2014.06.006

Basal, A. (2015). The implementation of a flipped classroom in foreign language teaching. Turkish Online Journal of Distance Education, 16(4), 28-37. doi: 10.17718/tojde.72185

Bergmann, J., \& Sams, A. (2012). Flip your classroom: Reach every student in every class every day. Washington, DC: Internal Society for Technology in Education.

Bishop, J. L., \& Verleger, M. A. (2013, June). The flipped classroom: A survey of the research. In ASEE National Conference Proceedings, Atlanta, GA. 30(9), 1-18. Retrieved from http://www.asee.org/file server/papers/attachment/file/o003/3259/6219.pdf

Büyüköztürk, Ş. (2016). Data analysis handbook for social sciences. Ankara: Pegem A Yayıncllı.

Chen Hsieh, J. S., Wu, W.C.V., \& Marek, M.W. (2017). Using the flipped classroom to enhance EFL learning. Computer Assisted Language Learning, 3o(1-2), 1-21. doi: 10.1080/09588221.2015.1111910

Chyr, W. L., Shen, P. D., Chiang, Y. C., Lin, J. B., \& Tsai, C. W. (2017). Exploring the effects of online academic help-seeking and flipped learning on improving students' learning. Educational Technology \& Society, 20 (3), 11-23. Retrieved from http://www.jstor.org/stable/26196116

Cohen J. (1988). Statistical power analysis for the behavioral sciences. Hillsdale, NJ: Lawrence Erlbaum Associates.

Crouch, C. H., \& Mazur, E. (2001). Peer instruction: Ten years of experience and results. American Journal of Physics, 69(9), 970-977. doi: 10.1119/1.1374249

Davies, R. S., Dean, D. L., \& Ball, N. (2013). Flipping the classroom and instructional technology integration in a college-level information systems spreadsheet course. Educational Technology Research and Development, 61(4), 563-580. Retrieved from https://link.springer.com/article/10.1007/s11423-013-9305-6

Erkuş, A. (2014). Scale development and measurement for psychology (pp. 140). Ankara: Pegem Yayınları.

Flipped Learning Network. (2014). Retrieved from http://flippedlearning.org/definition-of-flippedlearning/ 
Gillispie, V. (2016). Using the flipped classroom to bridge the gap to generation Y. Ochsner Journal, 16(1), 32-36. Retrieved from http://www.ochsnerjournal.org/doi/abs/10.1043/TOJ-15o074? code $=$ occl-site

Graziano, K. J. (2017). Peer teaching in a flipped teacher education classroom. TechTrends, 61(2), 121129. doi: $10.1007 / \mathrm{s} 11528-016-0077-9$

Hamdan, N., McKnight, P., McKnight, K., \& Arfstrom, K. M. (2013). The flipped learning model: A white paper based on the literature review titled "A review of flipped learning." Arlington, VA: Flipped Learning Network.

Herreid, C. F., \& Schiller, N. A. (2013). Case studies and the flipped classroom. Journal of College Science Teaching, 42(5), 62-66. Retrieved from https://www.jstor.org/stable/i40145230

Hsu, T. C. (2017). Behavioural sequential analysis of using an instant response application to enhance peer interactions in a flipped classroom. Interactive Learning Environments, 1-15. doi: $\underline{10.1080 / 10494820.2017 .1283332}$

Janotha, B. (2016). Improving student achievement with flipped classroom pedagogy. Nursing Research, 65(2), E100-E101. Retrieved from http://search.ebscohost.com/login.aspx?direct=true\&db=a9h\&AN=113905419\&site=ehostlive

Johnson, R. B., \& Onwuegbuzie, A. J. (2004). "Mixed methods research: A research paradigm whose time has come". Educational Researcher, 33(7), 14-26. Retrieved from http://journals.sagepub.com/doi/abs/10.3102/0013189X033007014

Johnston, B. M. (2017). Implementing a flipped classroom approach in a university numerical methods mathematics course. International Journal of Mathematical Education in Science and Technology, 48(4), 485-498. doi: 10.1080/0020739X.2016.1259516

Kahoot Application. (2016). Kahoot mobile app. Retrieved from https://kahoot.com/

Khan Academy. (2016). Retrieved from https://www.khanacademy.org/

Kim, M. K., Kim, S. M., Khera, O., \& Getman, J. (2014). The experience of three flipped classrooms in an urban university: An exploration of design principles. The Internet and Higher Education, 22, 37-50. doi: 10.1016/j.iheduc.2014.04.003

Kong, S. C. (2014). Developing information literacy and critical thinking skills through domain knowledge learning in digital classrooms: An experience of practicing flipped classroom strategy. Computers \& Education, 78, 160-173. doi: 10.1016/i.compedu.2014.05.009

Lage, M. J., Platt, G. J., \& Treglia, M. (2000). Inverting the classroom: A gateway to creating an inclusive learning environment. The Journal of Economic Education, 31(1), 30-43. doi: $\underline{10.1080 / 00220480009596759}$

Lincoln, Y. S., \& Guba, E. G. (1985). Naturalistic inquiry (Vol. 75). Beverly Hills, CA: Sage 
Pierce, R., \& Fox, J. (2012). Vodcasts and active-learning exercises in a "flipped classroom" model of a renal pharmacotherapy module. American Journal of Pharmaceutical Education, 76(10), 196. doi: $10.5688 /$ ajpe 610196

Pintrich, P.R. (2000). The role of goal orientation in self-regulated learning. In Boekaerts, M., Pintrich, P.R., \& M. Zeidner (Eds.), Handbook of self-regulation (pp. 451-502). San Diego, CA.: Academic Press.

Ray, B. B., \& Powell, A. (2014). Preparing to teach with flipped classroom in teacher preparation programs. In J. Keengwe, G. Onchwari, \& J.N. Oigara (Eds.) Promoting active learning through the flipped classroom model. Hershey: IGI Global.

Roehling, P. V., Root Luna, L. M., Richie, F. J., \& Shaughnessy, J. J. (2017). The benefits, drawbacks, and challenges of using the flipped classroom in an introduction to psychology course. Teaching of Psychology, 44(3), 183-192. doi: $10.1177 / 0098628317711282$

Sherer, P., \& Shea, T. (2011). Using online video to support student learning and engagement. College Teaching, 59(2), 56-59. Retrieved from https://www.tandfonline.com/doi/abs/10.1080/87567555.2010.511313

Siegle, D. (2014). Technology: Differentiating instruction by flipping the classroom. Gifted Child Today, 37(1), 51-55. doi: 10.1177/1076217513497579

Smallhorn, M. (2017). The flipped classroom: A learning model to increase student engagement not academic achievement. Student Success, 8(2). doi: 10.5204/ssj.v8i2.381

Song, Y., \& Kapur, M. (2017). How to flip the classroom- "Productive failure or traditional flipped classroom" pedagogical design? Journal of Educational Technology \& Society, $20(1), 292$. Retrieved from https://www.jstor.org/stable/pdf/jeductechsoci.20.1.292.pdf

Sun, J. C. Y., \& Wu, Y. T. (2016). Analysis of learning achievement and teacher-student interactions in flipped and conventional classrooms. The International Review of Research in Open and Distributed Learning, 17(1). doi: 10.19173/irrodl.v17i1.2116

Talley, C. P., \& Scherer, S. (2013). The enhanced flipped classroom: Increasing academic performance with student-recorded lectures and practice testing in a "flipped" STEM course. The Journal of Negro Education, 82(3), 339-347. doi: 10.7709/jnegroeducation.82.3.0339

Toto, R., \& Nguyen, H. (2009). Flipping the work design in an industrial engineering course. ASEE/IEEE Frontiers in Education Conference. San Antonio, TX. Retrieved from https://ieeexplore.ieee.org/stamp/stamp.jsp?tp=\&arnumber $=5350529$

Weinstein, C. E., \& Mayer, R. (1986). The teaching of learning strategies. In M. Wittrock (Eds.), Handbook of research on teaching and learning (pp. 315-327). New York, NY: Macmillan.

Wiginton, B. L. (2013). Flipped instruction: An investigation into the effect of learning environment on student self-efficacy, learning style, and academic achievement in an algebra I classroom. 
(Doctoral dissertation). The University of Alabama. Retrieved from https://search.proquest.com/docview/1505373684?pq-origsite=gscholar

Ylldırım, A. \& Şimşek, H. (2008). Qualitative research methods in social sciences. (Ed.). Ankara: Seçkin Yayıncılık.

Yilmaz, R. (2017). Exploring the role of e-learning readiness on student satisfaction and motivation in flipped classroom. Computers in Human Behavior, 70, 251-260. doi: 10.1016/j.chb.2016.12.085

Zengin, Y. (2017). Investigating the use of the Khan Academy and mathematics software with a flipped classroom approach in mathematics teaching. Journal of Educational Technology \& Society, 2O(2), 89-100. Retrieved from http://www.jstor.org/stable/90002166

Zhonggen, Y., \& Wang, G. (2016). Academic achievements and satisfaction of the clicker-aided flipped business English writing class. Journal of Educational Technology \& Society, 19(2), 298. Retrieved from http://www.jstor.org/stable/jeductechsoci.19.2.298

\section{Athabasca}

University

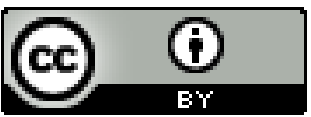

